\title{
Isolation and Assessment of Antibiotic Response Pattern of Heat Resistant Staphylococcus aureus from Milk
}

\author{
Ligimol James", A.K. Beena, V. Aparna Sudhakaran and K.S. Praseeda \\ Department of Dairy Microbiology, College of Dairy Science and Technology, \\ Mannuthy-680651, Thrissur, India \\ *Corresponding author
}

\begin{tabular}{|l|}
\hline Ke y w o r d s \\
$\begin{array}{l}\text { S aureus, Antibiotic } \\
\text { resistance, Heat } \\
\text { resistance, Minimum } \\
\text { inhibitory concentration }\end{array}$ \\
\hline Article Info \\
\hline $\begin{array}{l}\text { Accepted: } \\
\text { 22 April } 2018 \\
\text { Available Online: } \\
\text { 10 May } 2018\end{array}$ \\
\hline
\end{tabular}

\section{Introduction}

Milk, one of the most nutritionally complete foods, adds high-quality protein, fat, milk sugar, essential minerals, and vitamins to our diet. The nutritional components that make milk an important part of the human diet also support the growth of the microorganisms. So this nutrient rich medium could act as vehicles of disease transmission and thus is associated with disease outbreaks of major proportion. Milk and its derivatives are considered as a major source of Staphylococcus aureus associated diseases in human beings (Zecconi and Piccinini, 1998). S. aureus get access to milk either by direct excretion from udders with clinical or subclinical Staphylococcal mastitis or by contamination from the 
environment during handling of raw milk (Scherrer et al., 2004; Jorgensen et al., 2005). Staphylococci are non-motile, non-spore forming facultative anaerobes that grow by aerobic respiration or by fermentation. They are mesophils with optimum growth temperature in the range from $37^{\circ} \mathrm{C}$ to $40^{\circ} \mathrm{C}$. Temperatures higher than $46^{\circ} \mathrm{C}$ are not acceptable for majority of the strains, but some may grow up to $50{ }^{\circ} \mathrm{C}$ (Medved'ová and Valík, 2012). However there are reports of isolation of heat resistant $S$ aureus from different food samples (Beena et al., 2014; Montanari et al., 2015; Yaniarti et al., 2017). Pasteurization, the process of heating every particle of milk to at least $63^{\circ} \mathrm{C}$ for $30 \mathrm{~min}$ or $72^{\circ} \mathrm{C}$ for $15 \mathrm{sec}$ or to any temperature-time combination which is equally efficient in approved and properly operated equipment is one of the major thermal processes the dairy industry relies on to assure the safety and quality of the milk. So evidences of any pathogens capable of surviving this process are of great public health relevance. Considering the public health threat posed by the prevalence of multiple drug resistance in heat resistant strains of $S$ aureus, it was felt appropriate to carry out a study to evaluate the antibiotic resistance pattern in heat resistant $S$ aureus from milk.

\section{Materials and Methods}

Isolation, physiological, biochemical and molecular level identification of selected Staphylococcus aureus isolates

Raw milk samples were subjected to a heat treatment of $72^{\circ} \mathrm{C}$ for two or three minutes and cooled immediately. A temperature control was kept along with the sample to ensure that heat treatment of samples was proper Appropriate dilutions of the heat treated samples were pour plated on Baird-Parker agar (HiMedia, Mumbai) and incubated at $37^{\circ} \mathrm{C}$ for $48 \mathrm{~h}$. Five typical colonies (shiny black with an opaque ring, surrounded by a clear halo) were randomly selected from the plate and subjected to preliminary identification tests: Gram staining and catalase test. The isolates were stored in nutrient agar slants at $4^{0} \mathrm{C}$ and activated in nutrient broth to carry out further studies. Carbohydrate fermentation (Barrow and Feltham, 1993) and coagulase tests (tube method, Coagulase plasma, HiMedia, Mumbai, as per manufacturer's directions) were also done as part of biochemical identification and characterization.

For the molecular level identification of the isolates, DNA of $24 \mathrm{~h}$ old cultures were extracted using the HiPurA Bacterial Genomic DNA Purification kit (Hi Media, Mumbai) as per the manufacturer's instructions. Fragments of the genes of interest were amplified using standard PCR protocol using the primers Forward primer (Sa442-1, 5'-AAT CTT TGTCGG TAC ACG ATA TTC TTC ACG3') and Reverse primer (Sa442-2, 5'-CGT AAT GAG ATT TCA GTA GAT AAT ACA ACA -3'). The $100 \mu$ reaction mixture comprised of $2 \mu \mathrm{l}$ each of $0.4 \mu \mathrm{M}$ primers (Sigma, USA), $10 \mu \mathrm{l}$ of $25 \mathrm{mM} \mathrm{MgCl}_{2}$ (Sigma, USA), $10 \mu 1$ of PCR 10X assay buffer (GeNei), $10 \mu \mathrm{l}$ of dNTPs $(10 \mathrm{mM}), 0.6 \mu \mathrm{l}$ of 0.05 units/ $\mathrm{ml}$ of Taq DNA polymerase (Sigma, USA), $59.4 \mu \mathrm{l}$ of nuclease free water and $6 \mu \mathrm{l}$ of template DNA sample. Amplification was carried out in a thermal cycler (BIO RAD T100) as follows: initial denaturation at $95{ }^{\circ} \mathrm{C}$ for $1 \mathrm{~min}$, followed by 35 cycles each consisting of denaturation at 95 ${ }^{\circ} \mathrm{C}$ for $1 \mathrm{~min}$, annealing at $56^{\circ} \mathrm{C}$ for $30 \mathrm{sec}$, extension at $72{ }^{\circ} \mathrm{C}$ for $45 \mathrm{sec}$, followed by a final five -minute extension step at $72{ }^{\circ} \mathrm{C} .10$ $\mu 1$ of the reaction products were resolved by electrophoresis in a $1.5 \%$ agarose gel containing $0.5 \mu \mathrm{g} / \mathrm{ml}$ of ethidium bromide in 1X TAE buffer (Tris Acetate EDTA, HiMedia, Mumbai) buffer at $50 \mathrm{~V}$. A $100 \mathrm{bp}$ DNA ladder $(200 \mathrm{pg} / \mu \mathrm{l}$, HiMedia, Mumbai) 
was included as a reference. The gel was observed and photographed in the Gel documentation system (G-BOX, Syngene).

Assessment of antibiotic sensitivity of the selected isolates

\section{Disc diffusion assay}

The susceptibility of the isolates to different antibiotics was determined as per the methods of Bauer et al., (1959). For this Mueller Hinton agar (MHA, HiMedia, Mumbai) plates were prepared and active cultures of isolates were swabbed over the surface of the plate. Nine different antibiotic discs (Ampicillin (10 $\mu \mathrm{g})$, Amoxicillin $(10 \mu \mathrm{g})$, Amoxyclav $(30 \mu \mathrm{g})$, Ceflazidime $(30 \mu \mathrm{g})$, cefixime $(30 \mu \mathrm{g})$, Cefepime (30 $\mu \mathrm{g})$, Oxacillin $(5 \mu \mathrm{g})$, Erythromycin $(15 \mu \mathrm{g})$, Gentamicin $(50 \mu \mathrm{g})$, Tetracycline $(30 \mu \mathrm{g})$ and Linezolid $(30 \mu \mathrm{g})$ (HiMedia, Mumbai) were placed over the surface of the inoculated plate and incubated at $37^{\circ} \mathrm{C}$ for 24 hours. Diameter of the zone of clearance developed around the discs were measured and recorded. The isolates were graded as either resistant/sensitive based on the antibiotic sensitivity chart provided by the supplier (HiMedia, Mumbai).

\section{Determination of minimum inhibitory concentration of selected antibiotics}

The minimum inhibitory concentration (MIC) for four different antibiotics (Ampicillin, Erythromycin and Tetracycline) for the isolates were determined using EZY MICTM and $\mathrm{HiComb}^{\mathrm{TM}}$ MIC strips (HiMedia, Mumbai) as per the manufacturer's instructions. For this active culture of isolates were inoculated at $1 \%$ level to nutrient broth and incubated at $37^{\circ} \mathrm{C}$ until an optical density of 0.08 at $620 \mathrm{~nm}$ was obtained. These O.D. adjusted active cultures were swabbed on preprepared MHA plates, the antibiotic strips were then placed on the plates and incubated at $37^{\circ} \mathrm{C}$ for 24 hours and read the MIC as the concentration where the ellipse intersects the MIC scale on the strip. Resistance/sensitivity was determined based on the interpretive data provided by the manufacturer of the strips.

\section{Results and Discussion}

\section{Isolation of $S$. aureus from heat treated milk}

On pour plating of milk heat treated at $72^{\circ} \mathrm{C}$ for two or three minutes on Baird Parker agar medium typical colonies of $S$. aureus appeared as black and shiny with narrow white margins and surrounded by clear zone extending into the opaque medium (Figure 1). From the typical colonies, five were randomly selected (Table 1) and subjected to various tests to further characterize them.

\section{Physiological, biochemical and molecular level characterization of selected isolates}

Primary identification of the isolates was carried out by Gram staining and catalase test. Staphylococcus aureus are gram positive cocci which are catalase positive (Barrow and Feltham, 1993). All the isolates obtained in this work were found to be catalase positive, Gram positive cocci in clusters (Fig. 2). When streaked on Mannitol salt agar (MSA) all of them formed small yellow colonies and were presumptively identified as $S$ aureus as the growth and production of yellow colonies in MSA is regarded as a presumptive tool in the identification of $S$. aureus (Fig. 3, Shittu et al., 2006).

Development of yellow colonies was considered as a characteristic for the differentiation of coagulase-positive staphylococci from coagulase-negative staphylococci (CNS, Duguid, 1989) earlier, but now it is known that some CNS can also produce yellow colonies on MSA (Zadik et al., 2001; Shittu et al., 2006). 
Carbohydrate fermentation pattern of all the five isolates were in agreement with that given in Bergey's manual (Schleifer and Bell, 2009) in terms of their ability to ferment maltose, mannitol, fructose, sucrose, trehalose (Table 2).

Fermentation pattern of the sugars xylose, raffinose and mannose varied in between strains as well as from the Bergey's manual. Surprisingly none of the isolates could ferment cellobiose, though it is fermentable as per Bergey's manual. Such variations in biochemical reactions of $S$. aureus isolates are reported by El-Hadedy and $\mathrm{Abu}$ El-Nour (2012). All the isolates were found to be coagulase positive (Table 2 ) on performing the tube test indicating the presence of unbound extracellular coagulase.

Agarose gel electrophoresis of the PCR products revealed the presence of bands slightly higher than 100 bp size (Fig. 4). This is in agreement with Singh and Prakash (2012) who reported 108bp sized PCR products for S.aureus when species specific primers as that in current study were used.

Isolation and confirmation of the presence of $S$ aureus in milk subjected to heat treatments exceeding that of pasteurization raises an alarm. As observed in the current study other studies also reported the isolation of heat resistant $S$. aureus from food samples (Parente and Mazzatura 1991; Nema et al., 2007; Dewanti-Hariyadi et al., 2011).

\section{Assessment of antibiotic sensitivity of the selected isolates}

\section{Disc diffusion assay}

In general, differences were observed among isolates in their antibiotic sensitivity or resistance patterns (Fig. 5 and Table 4). Isolate 1 was found to be sensitive to all tested antibiotics except linezolid, one of the protein synthesis inhibitors tested. Isolate 3 being resistant to four antibiotics (ampicillin, amoxyclav, gentamicin and linezolid) was identified as the most resistant isolate and could be categorized as a multi-drug resistant $S$ aureus (resistance to three or more antibiotics, Chandrasekharan et al., 2014). Isolate 4 was found to be resistant to only one antibiotic, ampicillin.

Two isolates, namely isolates 2 and 5 exhibited resistance to two antibiotics. All the isolates were sensitive or intermediate to the antibiotics amoxicillin, ceftazidime (a thirdgeneration cephalosporin), cefapime (a fourthgeneration cephalosporin), erythromycin (a macrolide antibiotic) and tetracycline (Table 3).

It is noteworthy that two out of the five isolates were resistant to linezolid, an antiMRSA (Methicillin resistant S. aureus) drug approved as an alternative to vancomycin for infections caused by MRSA.

This observation is markedly different from the earlier report of sensitivity of all Staphylococcus aureus isolates to linezolid (Niveditha and Sujatha, 2015).

Out of the six cell wall synthesis inhibiting and four protein synthesis inhibiting antibiotics tested, highest number of resistant isolates (three each) were obtained for ampicillin and gentamicin, a protein synthesis inhibiting aminoglycoside.

Considering that the isolates were obtained from milk, the comparatively high resistance observed against these antibiotics could be due to the facts that Staphylococcus aureus is a major pathogen associated with bovine clinical and subclinical mastitis (Bhatt et al., 2011; Verma et al., 2018) and these drugs are commonly used for mastitis therapy (De Oliveira et al., 2000; Manimaran et al., 2014) 
Fig.1 S. aureus colonies on Baird Parker agar

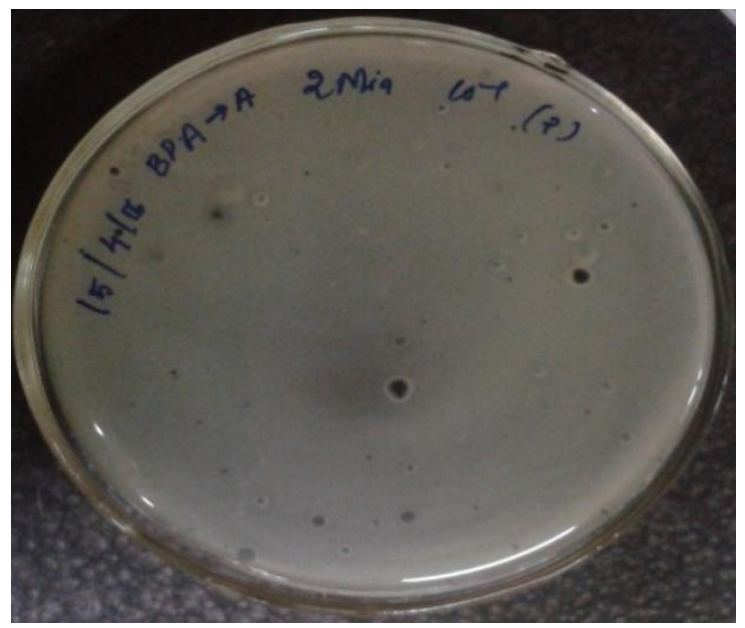

Fig.2 Microscopic appearance of Gram stained S. aureus

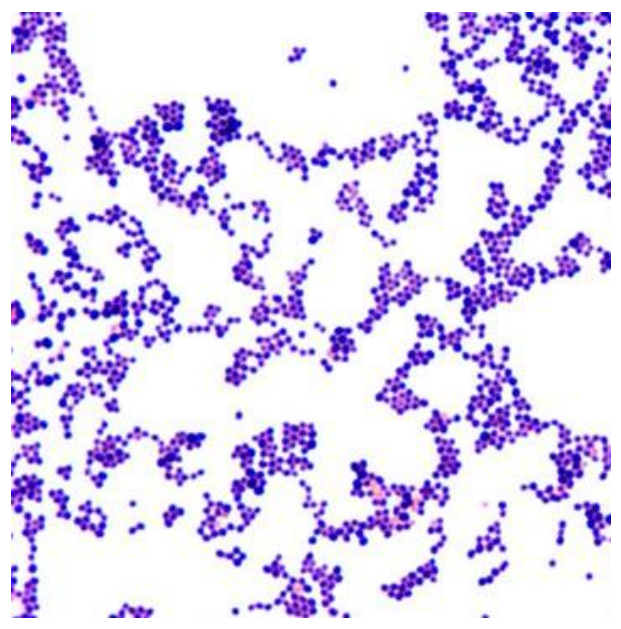

Fig.3 Growth of Staphylococcus aureus isolates on mannitol salt agar medium

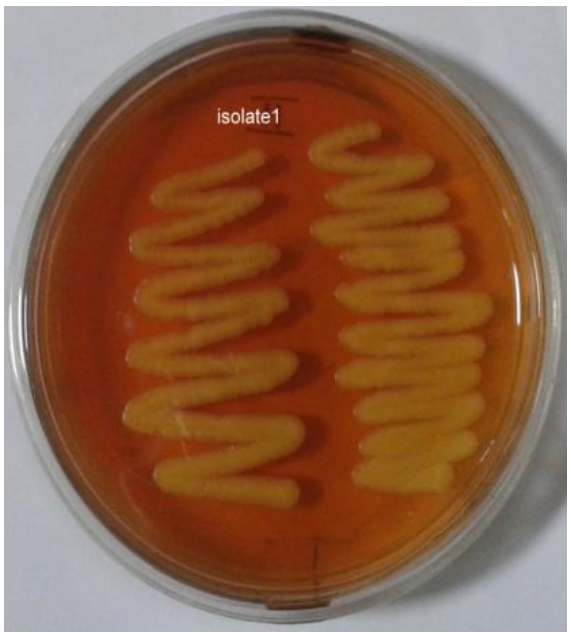


Fig.4 Electrophoretic profile of PCR products of $S$. aureus isolates amplified by the species specific primers Sa442-1 and Sa442-2.Lane 1- 100bp marker, Lanes 2-6-Isolates 1-5

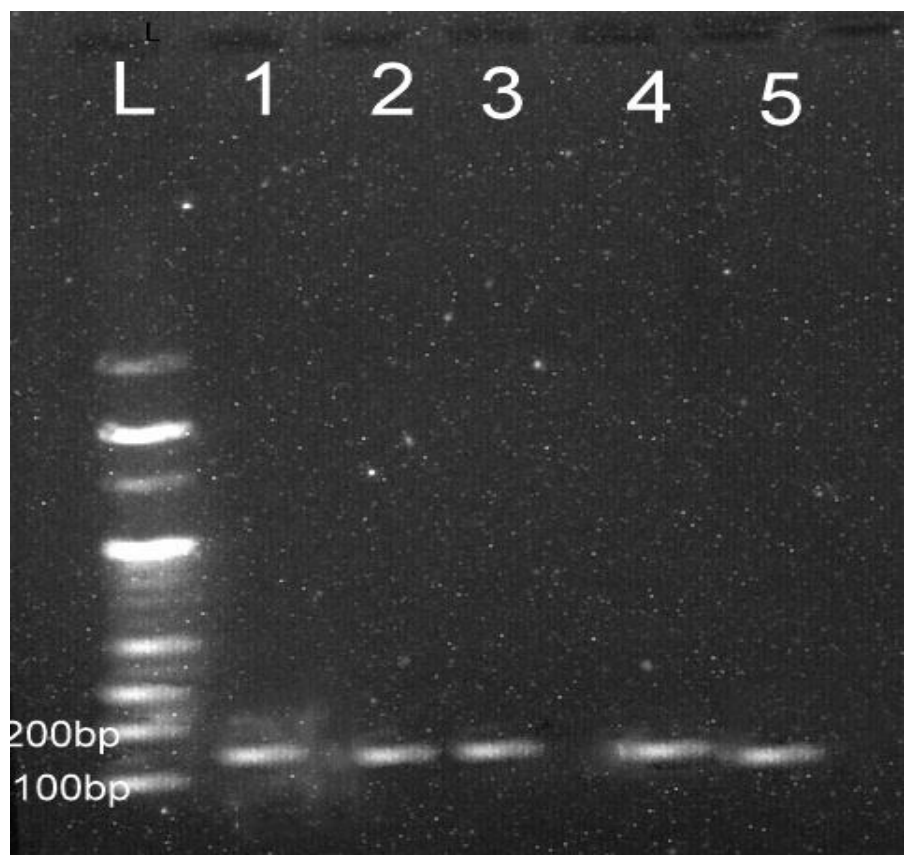

Fig.5 Disc diffusion assay for antibiotic susceptibility testing

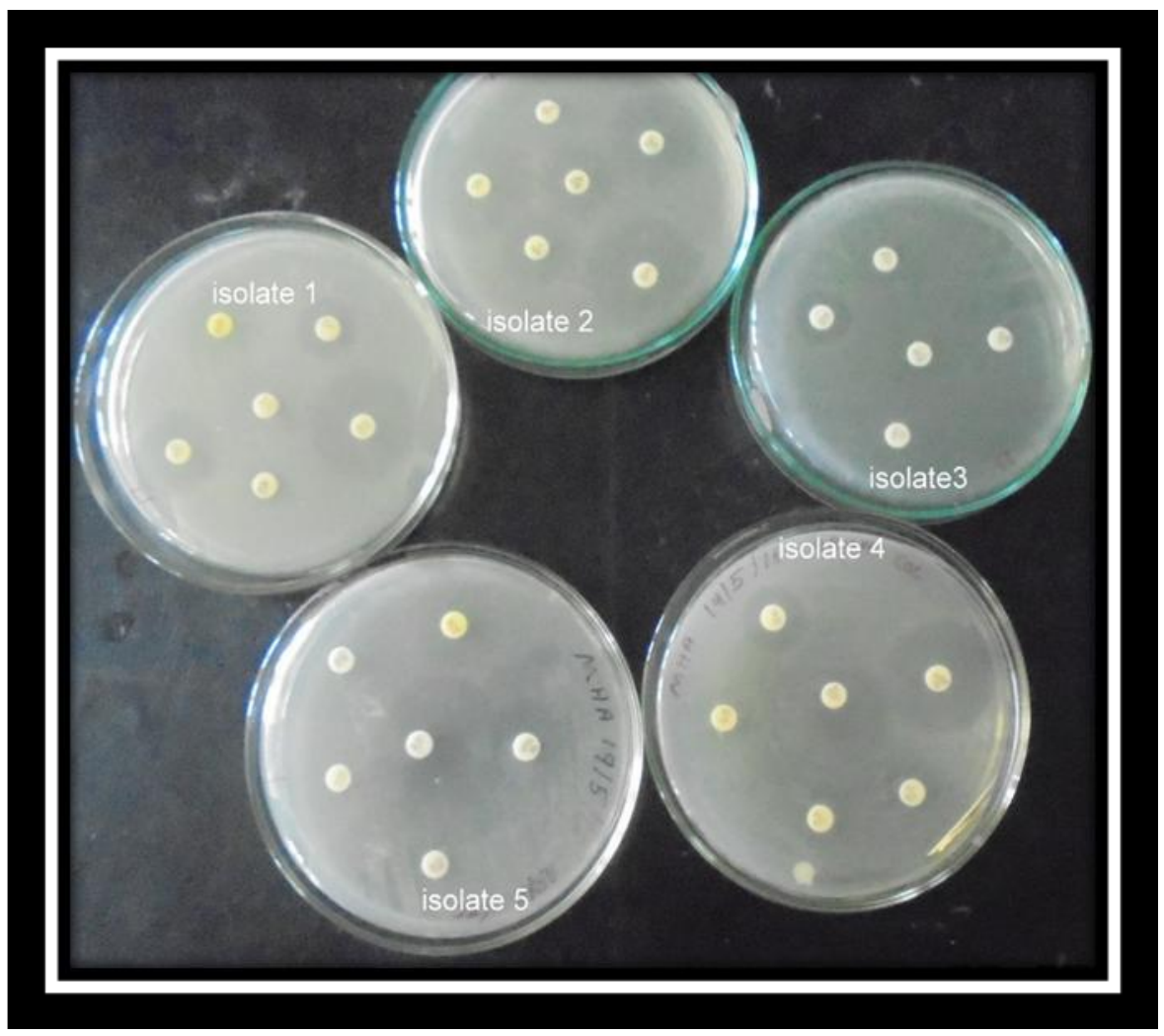


Fig.6 Determination of MIC values using MIC strips

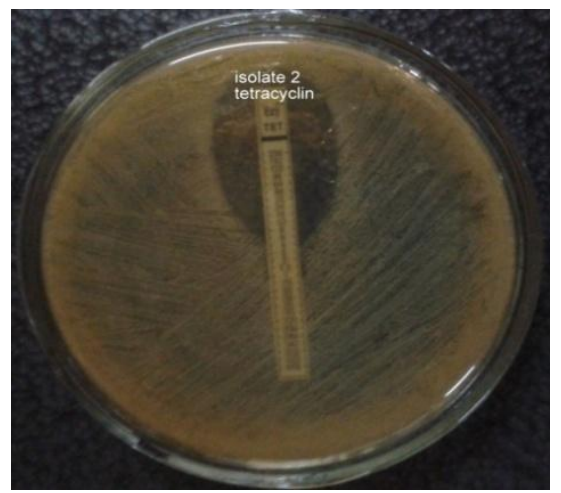

Table.1 Details of isolates selected

Isolate no:

\begin{tabular}{|l|}
\hline Isolate 1 \\
\hline Isolate 2 \\
\hline Isolate 3 \\
\hline Isolate 4 \\
\hline Isolate 5 \\
\hline
\end{tabular}

Source of isolation

Milk heat treated at $72^{\circ} \mathrm{C} / 2$ minutes

Milk heat treated at $72^{\circ} \mathrm{C} / 2$ minutes

Milk heat treated at $72^{\circ} \mathrm{C} / 2$ minutes

Milk heat treated at $72^{\circ} \mathrm{C} / 3$ minutes

Milk heat treated at $72^{0} \mathrm{C} / 3$ minutes

Table.2 Carbohydrate fermentation by Staphylococcus aureus isolates

\begin{tabular}{|l|c|c|c|c|c|c|}
\hline Test & $\begin{array}{l}\text { Bergey's } \\
\text { manual }\end{array}$ & Isolate 1 & Isolate 2 & Isolate 3 & Isolate 4 & Isolate 5 \\
\hline Catalase test & + & + & + & + & + & + \\
\hline Carbohydrate fermentation & & & & & & \\
\hline Lactose & + & - & - & + & - & + \\
\hline Maltose & + & + & + & + & + & + \\
\hline Mannitol & + & + & + & + & + & + \\
\hline Fructose & + & + & + & + & + & + \\
\hline Sucrose & + & + & + & + & + & + \\
\hline Trehalose & + & + & + & + & + & + \\
\hline Xylose & - & + & - & - & - & + \\
\hline Cellobiose & - & + & + & + & + & + \\
\hline Raffinose & - & + & - & + & - & + \\
\hline Mannose & + & + & - & + & - & + \\
\hline Coagulase test & + t & + & + & + & + & + \\
\hline
\end{tabular}

+ - Positive reaction - Negative reaction 
Table.3 Resistance / Sensitivity of the isolates to the antibiotic tested

\begin{tabular}{|c|c|c|c|c|c|c|c|c|}
\hline $\begin{array}{c}\text { Sl } \\
\text { no: }\end{array}$ & $\begin{array}{l}\text { Antibiotic } \\
\text { tested }\end{array}$ & $\begin{array}{l}\text { Antibiotic } \\
\text { content/di } \\
\text { sc } \mu \mathrm{g}\end{array}$ & $\begin{array}{c}\text { Isolate } \\
1\end{array}$ & $\begin{array}{c}\text { Isolate } \\
2\end{array}$ & $\begin{array}{c}\text { Isolate } \\
\mathbf{3}\end{array}$ & $\begin{array}{c}\text { Isolate } \\
4\end{array}$ & $\begin{array}{c}\text { Isolate } \\
5\end{array}$ & $\begin{array}{l}\text { Number of } \\
\text { resistant } \\
\text { isolates }\end{array}$ \\
\hline 1 & Ampicillin & 10 & $\mathrm{~S}$ & $\mathrm{R}$ & $\mathrm{R}$ & $\mathrm{R}$ & S & 3 \\
\hline 2 & Amoxicillin & 10 & $\mathrm{~S}$ & $\mathrm{~S}$ & $\mathrm{~S}$ & S & $S$ & 0 \\
\hline 3 & Amoxyclav & 30 & S & S & $\mathrm{R}$ & S & $\mathrm{S}$ & 1 \\
\hline 4 & Ceftazidime & 30 & $\mathrm{~S}$ & I & I & I & $\mathrm{S}$ & 0 \\
\hline 5 & Cefepime & 30 & $\mathrm{~S}$ & $\mathrm{~S}$ & I & I & $\mathrm{S}$ & 0 \\
\hline \multirow[t]{2}{*}{6} & Oxacillin & 5 & S & S & S & S & $\mathrm{R}$ & 1 \\
\hline & $\begin{array}{c}\text { Number of } \\
\text { antibiotics to } \\
\text { which the isolate } \\
\text { was resistant }\end{array}$ & & 0 & 1 & 2 & 1 & 1 & \\
\hline \multicolumn{9}{|c|}{ b. } \\
\hline 1 & Erythromycin & 15 & I & I & S & S & I & 0 \\
\hline 2 & Gentamicin & 50 & S & $\mathrm{R}$ & $\mathrm{R}$ & S & $\mathrm{R}$ & 3 \\
\hline 3 & Tetracycline & 30 & $S$ & I & I & I & I & 0 \\
\hline \multirow[t]{2}{*}{4} & Linezolid & 30 & $\mathrm{R}$ & S & $\mathrm{R}$ & S & S & 2 \\
\hline & $\begin{array}{l}\text { Number of } \\
\text { antibiotics to } \\
\text { which the isolate } \\
\text { was resistant }\end{array}$ & & 1 & 1 & 2 & 0 & 1 & \\
\hline
\end{tabular}

R- Resistant, I - Intermediate, S-Sensitive

Table.4 MICs $(\mu \mathrm{g} / \mathrm{ml})$ of selected antibiotics (determined using E-strips) for $S$ aureus isolates and their resistance/ sensitivity (Alphabets in brackets are indicative of: $R$ - Resistant, IIntermediate, S-Sensitive)

\begin{tabular}{|l|l|c|c|c|c|c|}
\hline SI no: & $\begin{array}{l}\text { Antibiotic } \\
\text { tested }\end{array}$ & Isolate 1 & Isolate 2 & Isolate 3 & Isolate 4 & Isolate 5 \\
\hline $\mathbf{1}$ & Ampicillin & $0.001(\mathrm{~S})$ & $3(\mathrm{R})$ & $4(\mathrm{R})$ & $0.001(\mathrm{~S})$ & $0.01(\mathrm{~S})$ \\
\hline $\mathbf{2}$ & Erythromycin & $0.001(\mathrm{~S})$ & $8(\mathrm{R})$ & $2(\mathrm{~S})$ & $0.01(\mathrm{~S})$ & $0.001(\mathrm{~S})$ \\
\hline $\mathbf{3}$ & Tetracycline & $3(\mathrm{~S})$ & $2(\mathrm{~S})$ & $0.1(\mathrm{~S})$ & $8(\mathrm{I})$ & $6(\mathrm{I})$ \\
\hline
\end{tabular}




\section{Determination of minimum inhibitory concentration of selected antibiotics}

On determining the minimum inhibitory concentration of ampicillin, erythromycin and tetracycline for the isolates, marked differences were observed in their values for different isolates (Table 5). In the case of ampicillin, the minimum inhibitory concentrations ranged from 0.001 to $4 \mu \mathrm{g} / \mathrm{ml}$. For isolates 2 and 3, the resistance patterns obtained based on MIC values was in agreement with that obtained for disc diffusion assay. However in the case of Isolate 4 , there was difference between the results obtained for disc diffusion and MIC determination assays which needs to be further investigated. The widest range of MIC values was obtained for erythromycin: varying from 0.001 to $8 \mu \mathrm{g} / \mathrm{ml}$. Different from the 'intermediate resistant' grading obtained for isolate 2 based on the disc diffusion assay, it was graded as resistant on the basis of MIC value of erythromycin whereas for all the other isolates the observations were agreeing with each other. In the case of the other protein synthesis inhibitor tested, tetracycline the MIC values ranged from 0.1 to $8 \mu \mathrm{g} / \mathrm{ml}$, the highest MIC value being similar to that obtained for erythromycin (Fig. 6). As observed in the disc diffusion assay none of the isolates was found to be resistant to this antibiotic based on their MIC values. So in general, irrespective of some variations between the resistance /sensitivity pattern derived based on zone of inhibition (disc diffusion assay) and minimum inhibitory concentrations, majority of the observations were comparable with each other. Previous studies also reported different levels of agreement between E-test and disk diffusion in determining antimicrobial sensitivity depending on the types of specific organisms and antibiotics used in the studies (Erfani et al., 2011; Khalili et al., 2012). Such variations are also attributed to the type of antibiotic discs used due to differences in quality of discs from different manufacturers. However this does not stand in the current study as both were from the same manufacturers. So the differences observed could be attributed to the differences in the isolates.

Based on their MIC values three of the isolates, namely 1, 4 and 5 were not found to sensitive/intermediate to all the tested antibiotics. Isolate 3 was found to be resistant to ampicillin and isolate 2 to ampicillin and erythromycin.

Exposures to deleterious stresses force the stressed bacteria to undergo phenotypic and genotypic adaptations in order to reduce the impact of these stresses. Some of these adaptation mechanisms are found to impart cross protection against a range of apparently unrelated challenges including resistance to antibiotics. However no such cross protection effects between heat and antibiotic resistances were observed in the current study. Results of this work is in agreement with the reports of absence of any interrelationship between antibiotic resistance and heat resistance in $L$ monocytogenes (Walsh et al., 2001) and also between laboratory acquired antibiotic resistant mutation and heat resistance in Salmonella strains (Walsh et al., 2005).

Antibiotic resistance in bacteria is a critical problem that is globally recognized. Indiscriminate use of antibiotics/antimicrobial agents for prophylactic and therapeutic purposes is identified as major reasons for this threat. Due to their unique ability to quickly develop resistance to new antibiotics Staphylococcus aureus is widely recognized as the best example for the adaptive evolution of bacteria in this antibiotic era. Current study reports the presence of $S$ aureus in milk even after a heat treatment of $72^{\circ} \mathrm{C}$ for 3 minutes. This observation itself is of great relevance 
due to the risk associated with their ability to surive pasteurization, a process highly relied upon to safeguard the health of consumers. The resistance exhibited by the isolates against multiple antibiotics makes the situation still graver and also reemphasize the need for adoption of good agricultural /hygienic practices at all levels of production and processing to safeguard the health of consumers.

\section{References}

Barrow, C. I., and Feltham, R. K. A. 1993. Cowan and steel's; Manual for the identification of medical bacteria. $3^{\text {rd }}$ edition. Cambridge University Press. pp. 68-76.

Bauer, A. W., Perry, D. M. and Kirby, W. M. 1959. Single-disk antibiotic-sensitivity testing of staphylococci; an analysis of technique and results. AMA Arch. Int. Medicine 104(2):208-216.

Beena, A.K., James, L. and Jisna, T. 2014. Antibiotic response pattern of Staphylococcus aureus isolated from pasteurized milk and the milk sweetPedha. Int. J. Agri. Food Sci. Tech. 5(1):53-60.

Bhatt, V.D., M.S. Patel, C.G. Joshi and A. Kunjadia, 2011. Identification and antibiogram of microbes associated with bovine mastitis. Anim. Biotechnol., 22 (3): 163-169.

Chandrasekaran, D., Venkatesan, P., Tirumurugaan, K.G., Nambi, A.P., Thirunavukkarasu, P.S., Kumanan, K., Vairamuthu, S. and Ramesh S. 2014. Pattern of antibiotic resistant mastitis in dairy cows, Vet. World 7(6): 389-394.

De Oliveira, A.P., Watts, J.L., Salmon, S.A. and Aarestrup, F.M. 2000.Antimicrobial susceptibility of Staphylococcus aureus isolated from bovine mastitis in Europe and the United States. J. Dairy Sci. 83(4):855-862.
Dewanti-Hariyadi, R., Hadiyanto, J. and Purnomo, E. K. 2011. Thermal resistance of local isolates of $S$. aureus. As. J. Food Ag- Ind. 4(4):213-221.

Duguid, J. P. 1989. Staphylococcus: clusterforming Gram-positive cocci. In: Colle, J. G, Duguid, J.P., Fraser, A.G. and Marmion, B.P. (Ed.) Mackie and McCartney Practical Medical Microbiology, Thirteenth ed. Churchill Livingstone. New York, pp. 303-316.

El-Hadedy, D. and Abu El-Nour, S.A. 2012. Identification of Staphylococcus aureus and Escherichia coli isolated from Egyptian food by conventional and molecular methods. J. Genet. Eng. Biotechnol.10:129-135.

Erfani, Y., Rasti, A., Mirsalehian, A., Mirafshar S. M. and Ownegh, V. 2011. E-test versus disk diffusion method in determining multidrug resistant strains of Escherichia coli in urinary tract infection. Afr. J. Microbiol. Res. 5 (6): 608-611.

Jørgensen, H. J., Mørk, T., Høga ${ }^{\circ}$ sen, H. R. and Rørvik, L.M.2005.Enterotoxigenic Staphylococcus aureus in bulk milk in Norway. J. Appl. Microbiol. 99 (1): 58166.

Khalili, H., Soltani, R., Negahban, S., Abdollahi, A. and Gholami, K. 2012. Reliability of Disk diffusion test results for the antimicrobial susceptibility testing of nosocomial Gram-positive Microorganisms: Is E-test Method Better? Iran J. of Pharm. Res., 11 (2): 559-563.

Lopez, C.C., Vannini, L., Lanciotti, R. and Guerozoni, M.E. 1998. Microbiological quality of filled Pasta in relation to the nature of heat treatment. J. Food Prot., 61 (8):994-999.

Manimaran, A., Layek, S.S., Kumaresan, A., Prasad, S., Sreela, L., Boopathi, V., Kumar. K. and Venkatasubramanian, V. 2014. Estimation of antimicrobial drug 
usage for Treatment of clinical mastitis cases in organized dairy farm. Ind. J. Vet \& Anim. Sci. Res. 43 (2) 140 - 150. McMahon, M. A.S., Xu, J., Moore, J.E., Blair, I.S. and McDowell, D.A.2007. Environmental stress and antibiotic resistance in food-related pathogens. Appl. Environ. Microbiol. 73(1):211217.

Medved'ová, A. and Valík, L. 2012. Staphylococcus aureus: Characterisation and Quantitative Growth Description in Milk and Artisanal Raw Milk Cheese Production.In: Structure and Function of Food Engineering. Eissa, A.A. (Ed.) IntechOpen, Pp. 73. DOI: $10.5772 / 48175$.

Montanari, C., Serrazanetti, D. I., Felis, G., Torriani, S., Tabanelli, G., Lanciotti, R., Gardini, F. 2015. New insights in thermal resistance of staphylococcal strains belonging to the species Staphylococcus Staphylococcus lugdunensis and Staphylococcus aureus. Food Control. 50:605-612.

Nema, V., Agrawa, L R. and Ajay, K. G. 2007. Isolation and characterization of heat resistant enterotoxigenic Staphylococcus aureus from a food poisoning outbreak in Indian subcontinent. Int. J. Food Microbiol. 117(1): 29-35

Niveditha, N. and Sujatha, S.2015. Worrisome trends in rising minimum inhibitory concentration values of antibiotics against methicillin resistant Staphylococcus aureus-Insights from a tertiary care center, South India. Braz. J. Infect. Dis., 19(6):585-589.

Parente, E. and Mazzatura, A. 1991. Growth and heat resistance of Staphylococcus aureus in goat milk. Ital. J. Food Sci., 1: 27-37.
Scherrer, D., Corti, S., Muehlherr, J. E., Zweifel, C. and Stephan, R. 2004. Phenotypic and genotypic characteristics of Staphylococcus aureus isolates from raw bulk-tank milk samples of goats and sheep. Vet. Microbiol.101 (2):101-7.

Schleifer, K. and Bell, J.A. 2009. Family VIII Staphylocccaceae fam.nov. In: De Vos, P., Garrity, G.M., Jones, D., Krieg, N.R., Ludwig, W, Rainey, F.A., Schleifer K. and Whitman, W.B. (Ed.), Bergey's Manual of Systematic Bacteriology - The Firmicutes, Volume Three. Second ed. Springer, New York, p. 394.

Shittu, A., Lin, J., Morrison D. and Kolawole, D. 2006. Identification and molecular characterization of mannitol salt positive, coagulase-negative staphylococci from nasal samples of medical personnel and students. J. Med. Microbiol. 55(3):317-324.

Singh, P and Prakash, A. 2012. Species Specific PCR Based Rapid Detection of Staphylococcus aureus from Cottage Cheese, and its Sensitivity against Antibiotics and natural products. Internet J. Food Saf. 14:.89-92

Venkatesan, P., Tirumurugaan, K.G., Nambi, A.P., Thirunavukkarasu, P.S. Kumanan, K., Vairamuthu, S. and Ramesh, S. 2014. Pattern of antibiotic resistant mastitis in dairy cows. Vet. World 7(6): 389-394

Verma, H., Rawat, S., Sharma, N., Jaiswal, V. and Singh, R. 2018. Prevalence, bacterial etiology and antibiotic susceptibility pattern of bovine mastitis in Meerut. J. Entomol. Zool. Stud. 6(1): 706-709.

Walsh, C., Duffy, G., Sheridan, J.J., Fanning, S., Blair I.S. and McDowell, D.A. 2005. Thermal resistance of antibiotic resistant and antibiotic sensitive 
Salmonella spp, on chicken meat. J. Food Saf. 25(4): 288-302.

Walsh, C., Sheridan, J., Duffy, G., Blair I.S., McDowell, D.A. and Harrington, D. 2001. Thermal resistance of wild-type and antibiotic-resistant Listeria monocytogenes in meat and potato substrates. J. Appl. Micro. 90 (4):555560.

Yaniarti, M.N., Amarantini, C. and Budiarso, T.Y. 2017. The effect of temperature and Pasteurization time on Staphylococcus aureus isolates from dairy products.AIP Conference Proceedings 1908, 050003 (2017); doi: $10.1063 / 1.5012727$

Zadik, P. M., Davies, S., Whittaker, S. and Mason, C. 2001. Evaluation of a new selective medium for methicillinresistant Staphylococcus aureus. J Med. Microbiol. 50 (5): 476-479

Zecconi, A. and Piccinini, R. 1998. Staphylococcus aureus: a problem for Italian dairy herds. Bull. Int. Dairy Fed., 330: $25-26$.

\section{How to cite this article:}

Ligimol James, A.K. Beena, V. Aparna Sudhakaran and Praseeda, K.S. 2018. Isolation and Assessment of Antibiotic Response Pattern of Heat Resistant Staphylococcus aureus from Milk. Int.J.Curr.Microbiol.App.Sci. 7(05): 3322-3333. doi: https://doi.org/10.20546/ijcmas.2018.705.388 